\title{
SPECTRAL STUDIES OF POLYMER SUPPORTED CHELATES
}

\author{
A. Kumar ${ }^{1}$, D. Kumar' ${ }^{2}$, P. K. Gupta ${ }^{3 * *}$ and D. Dass ${ }^{4}$ \\ ${ }^{1}$ Department of Chemistry, Indira Gandhi National College, \\ Ladwa, Kurukshetra-136132, (Haryana) India \\ ${ }^{2}$ Department of Chemistry, National Institute of Technology, \\ Kurukshetra-136118, (Haryana) India \\ ${ }^{3}$ Department of Chemistry, Maharishi Markandeshwar (Deemed to be University), \\ Mullana-133207, Ambala, (Haryana) India \\ ${ }^{4}$ Department of Chemistry, Shri Krishan Institute of Engg. \& Tech., \\ Kurukshetra-136118, (Haryana) India \\ * E-mail: parveen.gupta@mmumullana.org
}

\begin{abstract}
The reaction between polystyrene 3-formylsalicylate and 2-Aminobenzylalcohol in DMF in the presence of ethyl acetate results in the formation of polystyrene $\mathrm{N}$-(2-hydroxymethylphenyl)-2'-hydroxybenzylideneimine-3'carboxylate (I). A benzene suspension of $\mathbf{I}$ reacts with mercaptoacetic acid undergoes cyclization and forms polystyrene N-(2-hydroxymethylphenyl)-C-(3'-carboxy-2'-hydroxyphenyl)thiazolidine-4-one, $\mathrm{PSCH}_{2}-\mathrm{LH}_{2}$ (II). A DMF suspension of II reacts with $\mathrm{Mn}(\mathrm{II})$ and $\mathrm{Cd}(\mathrm{II})$ ions and forms the corresponding polystyrene-anchored coordination compounds, [PSCH $\left.2-\mathrm{LHMn}(\mathrm{OAc})(\mathrm{DMF})_{3}\right]$ (III) and $\left[\mathrm{PSCH}_{2}-\mathrm{LHCd}(\mathrm{OAc})(\mathrm{DMF})\right]$ (IV). The polystyrene-anchored coordination compounds have been characterized on the basis of elemental analyses, spectral (IR, reflectance) studies and magnetic susceptibility measurements. II behave as a monobasic bidentate OS donor ligand in the coordination compounds. An octahedral structure for III and tetrahedral structure for IV are suggested. Keywords: Thiazolidine-4-one, Polystyrene-anchored coordination compounds, Magnetically dilute, Schiff base and Octahedral symmetry.
\end{abstract}

@ RASĀYAN. All rights reserved

\section{INTRODUCTION}

There is a growing interest in the preparation of Polymers incorporating metallic and semi-metallic subunits due to their chemical and physical properties as well as their numerous applications ${ }^{1}$. The immobilization of homogeneous catalysts onto the solid supports supplies potential for enlarging the utilities of the heterogeneous catalysts to the homogeneous systems. The polymeric supports have attained care because they are inert, nontoxic, nonvolatile, insoluble and often recyclable. Chloromethylated polystyrene crosslinked with divinylbenzene is one of the most extensively used supports.

The polymer-anchored coordination complexes have large scale interest due to their extensive application field. Transition metal complexes on polymer support have indicated various uses in organic synthesis ${ }^{2}$, as catalyst ${ }^{3}$, as Ion exchanger ${ }^{4}$ etc.

This technique of immobilization on inert support has ground much care due to their simple separation from the reaction mixture arriving at operational flexibility, selectivity, efficiency, stability, ease of handling and economy in various industrial processes. Insoluble polymer supports are more typically used as inert support for immobilizing the transition metal over cross-linked chloromethylated polystyrene ${ }^{5}$. Cross-linked polystyrene with specific properties is rather used as a catalyst as they are inert, non-volatile, non-toxic and recyclable. Polymer-anchored metal catalysts are known to catalyze various reactions like epoxidation of alkanes and alkenes ${ }^{6}$, oxidation of aromatic alcohols ${ }^{7}$, hydrogenation of alkenes ${ }^{8}$, etc.

This mainly arises from the wide range of coordination numbers, oxidation states and with geometries existing transition elements ${ }^{9}$ that offer the possibility of accessing a large diversity of metal-containing Rasayan J. Chem., 12(2), 577-582(2019) http://dx.doi.org/10.31788/RJC.2019.1225081 
polymeric materials with unusual conformational, mechanical and morphological characteristics, including thermal- and/or photo-processible properties required for industrial applications ${ }^{10}$.

The most important advantage of polymer-supported strategy is the simplification of product work up, easy separation and isolation ${ }^{11}$. It is known that the selective interaction of transition and heavy metal cations may be achieved by chelating receptors. Ligands containing Oxygen/Sulfur and Nitrogen donors groups have been of research interest because of the versatility of their steric and electronic properties ${ }^{12}$.

There has been considerable interest in the chemistry of thiazolidine-4-one ring system, which is a core structure in various synthetic pharmaceuticals displaying a broad spectrum of biological activities ${ }^{13,14}$.

These facts prompted us to explore the coordination behavior of polystyrene-anchored thiazolidine-4-one (II) derived from the Schiff base (I) (obtained from the condensation of polystyrene 3-formylsalicylate and 2-aminobenzylalcohol) towards $\mathrm{Mn}$ (II) and $\mathrm{Cd}(\mathrm{II})$ ions.

In this report, we describe the syntheses and characterization of polystyrene-anchored thiazolidine-4-one, $\mathrm{PSCH}_{2}-\mathrm{LH}_{2}$ (II) and its coordination compounds with the above ions.

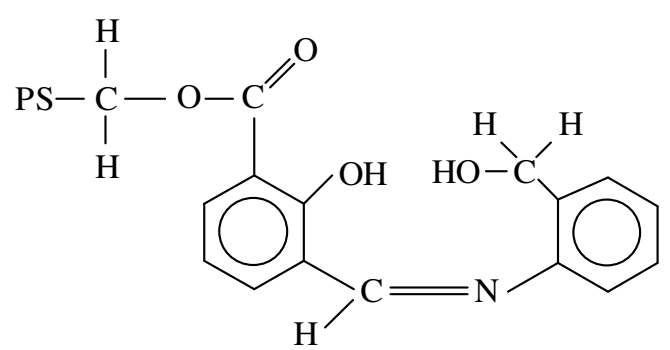

I

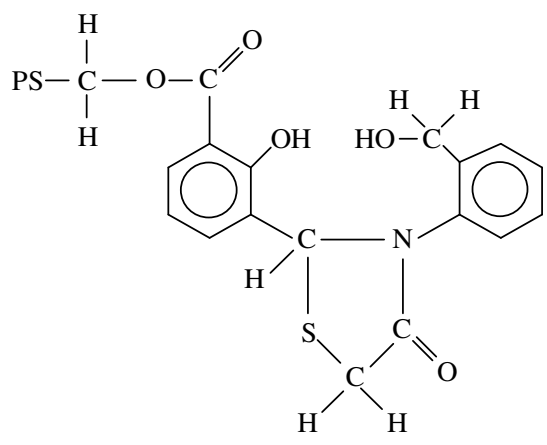

II

\section{Materials and Methods}

EXPERIMENTAL

Chloromethylated polystyrene, $\mathrm{PSCH}_{2}-\mathrm{Cl}$ (containing $1.17 \mathrm{mmol}$ of $\mathrm{Cl}$ per $\mathrm{g}$ of resin and $1 \%$ crosslinked with divinylbenzene) [Sigma Chemical Co (USA)]. manganese(II) acetate tetrahydrate, cadmium(II) acetate dihydrate [Sarabhai]; 2-Aminobenzylalcohol [Aldrich] were used as supplied for the syntheses. Polystyrene 3-formylsalicylate and 3-formylsalicylic acid were synthesized by following the reported procedures ${ }^{15}$. The elemental analyses, IR, reflectance spectral studies and magnetic susceptibility measurements were carried out as described in our previous report ${ }^{15}$.

\section{Synthesis of Polystyrene N-(2-hydroxymethylphenyl)-2'-hydroxybenzylideneimine-3'-carboxylate} (I)

Polystyrene 3-formylsalicylate (1.0 g) was allowed to suspend and swell in DMF (100 mL) for $45 \mathrm{~min}$. To this suspension, a DMF solution $(60 \mathrm{~mL})$ of 2-Aminobenzylalcohol $(0.58 \mathrm{~g}, 4.68 \mathrm{mmol})$ and ethyl acetate $(100 \mathrm{~mL})$ were added, while stirring magnetically. The mixture was refluxed for $8 h$ and then cooled to room temperature. The polystyrene-anchored Schiff base, I obtained was suction filtered, washed with DMF and ethyl acetate. It was dried in vacuo at room temperature.

\section{Synthesis of Polystyrene N-(2-hydroxymethylphenyl)-C-(3'-carboxy-2'-hydroxyphenyl) thiazolidine-4-one, $\mathrm{PSCH}_{2}-\mathrm{LH}_{2}$ (II)}

Mercaptoacetic acid ( $0.32 \mathrm{~g}, 3.51 \mathrm{mmol})$ was added to the swollen suspension of $\mathbf{I}(1.0 \mathrm{~g})$ in benzene (100 $\mathrm{mL}$ ). The mixture was refluxed for $12 h$ on a water bath and then cooled to room temperature. The solid product was filtered and washed with $10 \%$ sodium bicarbonate solution followed by chilled distilled water. The product was dried as mentioned above. IR bands $(\mathrm{KBr}): 1685 \mathrm{~cm}^{-1}[\mathrm{v}(\mathrm{C}==\mathrm{O})$ (thiazolidinone ring)], $1585 \mathrm{~cm}^{-1}[v(\mathrm{C}-\mathrm{N})$ (thiazolidinone ring) $], 1730 \mathrm{~cm}^{-1}[v(\mathrm{C}==\mathrm{O})($ ester $)], 3420 \mathrm{~cm}^{-1}[v(\mathrm{O}-\mathrm{H})($ phenolic $)]$, $1540 \mathrm{~cm}^{-1}[\mathrm{v}(\mathrm{C}-\mathrm{O})($ phenolic $)]$ and $840 \mathrm{~cm}^{-1}[\mathrm{v}(\mathrm{C}-\mathrm{S})$ (thiazolidinone ring) $]$ 


\section{Syntheses of Coordination Compounds of II}

$1.0 \mathrm{~g}$ of II was allowed to suspend and swell in DMF $(100 \mathrm{~mL})$ for $1 h$. A DMF solution of appropriate metal salt $(2.34 \mathrm{mmol})$ was added to the above suspension. The mixture was refluxed on a water bath for 8-10 $h$ and the products obtained were suction filtered, washed several times with ethyl acetate and DMF. The products were then dried as mentioned above.

\section{RESULTS AND DISCUSSION}

The reaction between polystyrene 3-formylsalicylate and 2-Aminobenzylalcohol in DMF in the presence of ethyl acetate results in the formation of polystyrene $\mathrm{N}$-(2-hydroxymethylphenyl)-2'hydroxybenzylideneimine-3'-carboxylate (I). The cyclization of I with mercaptoacetic acid in benzene forms polystyrene $\mathrm{N}$-(2-hydroxymethylphenyl)-C-(3'-carboxy-2'-hydroxyphenyl) thiazolidine-4-one, $\mathrm{PSCH}_{2}-\mathrm{LH}_{2}$ (II). A DMF suspension of II reacts with $\mathrm{Mn}$ (II) and $\mathrm{Cd}$ (II) ions and forms the polystyreneanchored coordination compounds of the types, $\left[\mathrm{PSCH}_{2}-\mathrm{LHMn}(\mathrm{OAc})(\mathrm{DMF})_{3}\right]$ (III) and $\left[\mathrm{PSCH}_{2}-\right.$ $\mathrm{LHCd}(\mathrm{OAc})(\mathrm{DMF})]$ (IV) respectively.

The formations of I (by the reaction of polystyrene 3-formylsalicylate and 2-aminobenzylalcohol, II (by the cyclization of I with mercaptoacetic acid) and the coordination compounds of II with Mn (II) and Cd (II) ions are depicted as per Schemes I, II and III respectively.

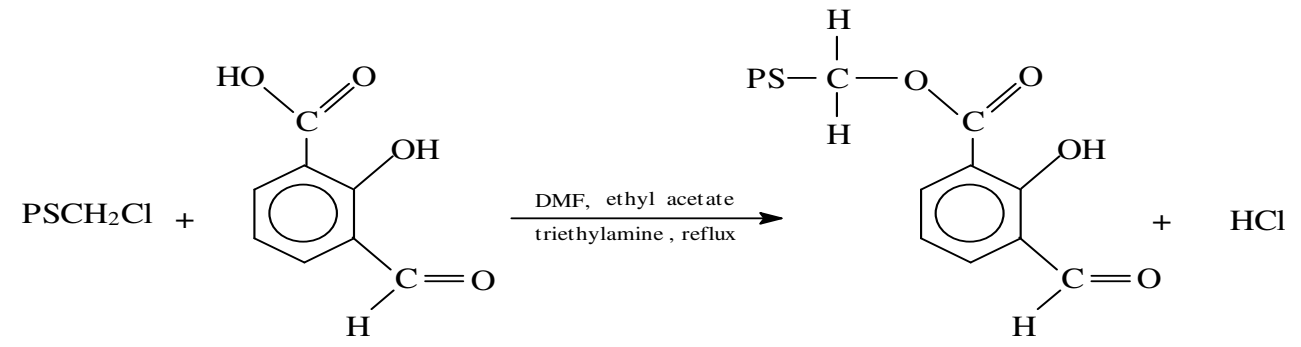

\section{$\mathrm{PSCH}_{2}$-Fsal}<smiles>O=Cc1cccc(C(=O)OCCP)c1O</smiles><smiles>Nc1ccccc1CO</smiles><smiles>CCOC(=O)c1cccc(C=NC2CCCCC2)c1O</smiles>

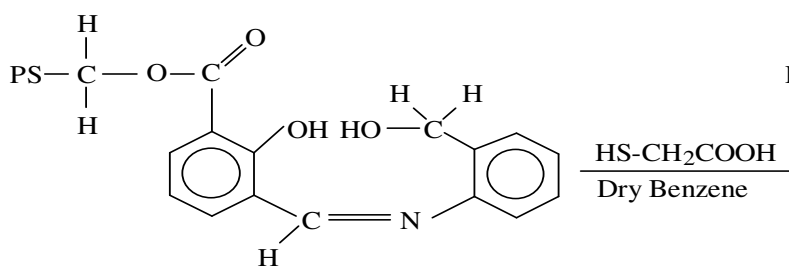

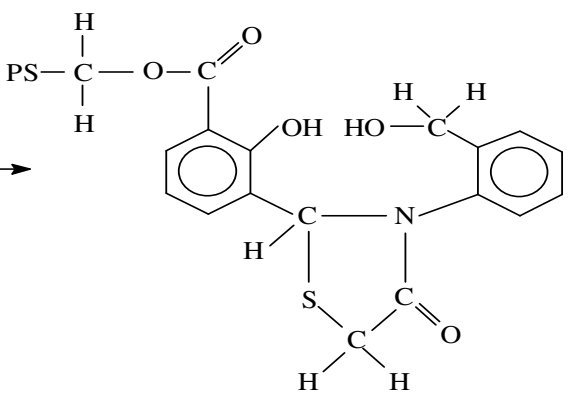


RASĀYAN J. Chem.

Vol. 12 | No. 2 |577-582 |April - June | 2019

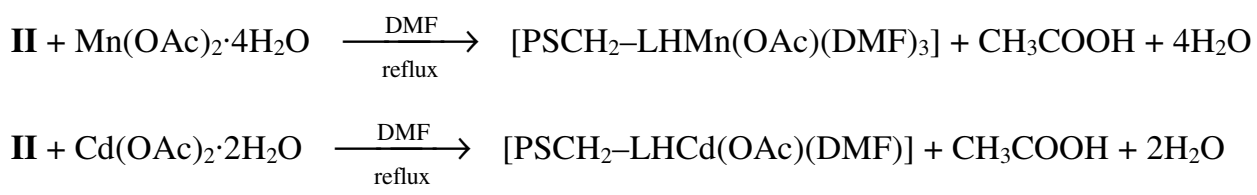

Scheme-III

The percent reaction conversion of III and IV are 73.6 and 70.1 respectively and the metal bind ing capacity of III and IV are 0.49 and $0.50 \mathrm{mmol}$ of corresponding metal per $\mathrm{g}$ of the resin respectively (Table-1).

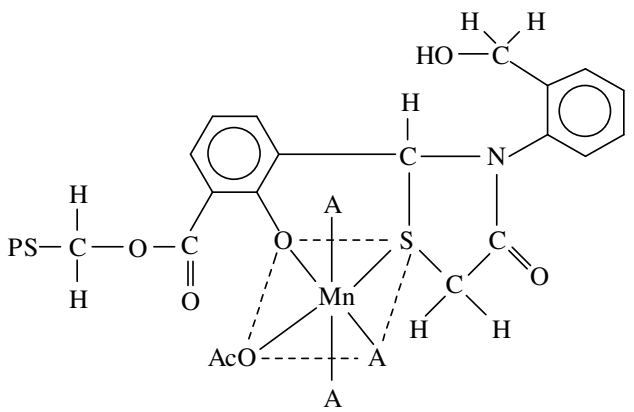

III

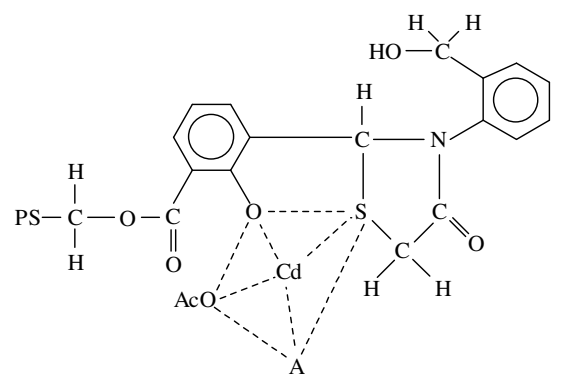

IV

Table-1: Analytical, MBC and PRC Values of Polystyrene-anchored Coordination Compounds of II ${ }^{\mathrm{a}}$

\begin{tabular}{|c|c|c|c|c|}
\hline \multirow[t]{2}{*}{ Compound } & \multicolumn{2}{|c|}{ Obsd (Calcd)\% } & \multirow{2}{*}{$\begin{array}{l}\mathrm{MBC}^{\mathrm{b}} \\
(\mathrm{mmol} / \mathrm{g} \\
\text { of resin) }\end{array}$} & \multirow[t]{2}{*}{ PRC } \\
\hline & $\mathrm{M}$ & DMF & & \\
\hline $\begin{array}{c}\mathrm{PSCH}_{2}- \\
\mathrm{LHMn}(\mathrm{OAc})(\mathrm{DMF})_{3} \\
](\mathrm{III})\end{array}$ & $2.7(3.67)$ & $\begin{array}{c}10.7 \\
(14.65)\end{array}$ & 0.49 & 73.6 \\
\hline $\begin{array}{c}\text { [PSCH}_{2-} \\
\mathrm{LHCd}(\mathrm{OAc})(\mathrm{DMF})] \\
(\mathrm{IV})\end{array}$ & $5.6(7.99)$ & $\begin{array}{c}3.64 \\
(5.19)\end{array}$ & 0.50 & 70.1 \\
\hline
\end{tabular}

${ }^{a}$ Abbreviations: $\mathrm{PSCH}_{2}-\mathrm{LH}_{2}=\mathrm{II}$

${ }^{\mathrm{b}} \mathrm{MBC}=[\mathrm{M} \%$ (observed) $\times 10] /($ atomic weight of metal)

${ }^{\mathrm{c}} \mathrm{PRC}=[\mathrm{M} \%$ (observed) $\times 100] / \mathrm{M} \%$ (calculated) on the basis of $100 \%$ reaction conversion of polystyrene-

anchored ligand to polystyrene-anchored coordination compounds.

\section{Infrared Spectral Studies}

The infrared spectra were recorded in $\mathrm{KBr}$ and the prominent peaks are shown in Table-2. The $v(\mathrm{C}=\mathrm{N})$ (azomethine) stretch of $\mathbf{I}\left(1635 \mathrm{~cm}^{-1}\right)$ disappears and a new band at $1585 \mathrm{~cm}^{-1}$ appears in II due to the $v(\mathrm{C}-\mathrm{N})$ (thiazolidinone ring) stretch ${ }^{16}$, indicating the formation of the corresponding thiazolidine-4one. The appearance of a new band at $840 \mathrm{~cm}^{-1}$ due to the $v(\mathrm{C}-\mathrm{S})$ (thiazolidinone ring) stretch ${ }^{17}$ further supports the formation of II. The $v(\mathrm{C}-\mathrm{O}) \phi \operatorname{stretch}^{18}$ of II occurs at $1540 \mathrm{~cm}^{-1}$ and shifts to higher energy by $5-10 \mathrm{~cm}^{-1}$ in the coordination compounds indicating the involvement of phenolic $\mathrm{O}$ atom. II also shows a broad band at $3420 \mathrm{~cm}^{-1}$ indicating the presence of $v(\mathrm{O}-\mathrm{H})($ phenolic) which disappear in the complexes. The $v(\mathrm{C}-\mathrm{O})$ (alcoholic) stretch of II occurs at $1225 \mathrm{~cm}^{-1}$ remain unchanged in the complexes. Due to steric grounds, we suggest the non-involvement of alcoholic (2-aminobenzylphenol moiety) $\mathrm{O}$ atom towards coordination. The $v(\mathrm{C}=\mathrm{O})$ (thiazolidinone) stretch ${ }^{19}$ of II occurs at $1685 \mathrm{~cm}^{-1}$. This band remains unchanged in the coordination compounds showing its non-involvement in coordination.

The $[v(\mathrm{C}-\mathrm{N})$ (thiazolidinone ring) $] \operatorname{stretch}^{16}$ of II occurs at $1585 \mathrm{~cm}^{-1}$ also remains unchanged in the coordination compounds. The $[v(\mathrm{C}-\mathrm{S})$ (thiazolidinone ring) $]$ stretch ${ }^{17}$ of II occurring at $840 \mathrm{~cm}^{-1}$ shifts to 
lower energy by $20-25 \mathrm{~cm}^{-1}$ in both the coordination compounds.

Table-2: IR, Reflectance Spectral Data $\left(\mathrm{cm}^{-1}\right)$ and Magnetic Moments of Polystyrene-anchored Coordination Compounds

\begin{tabular}{|c|c|c|c|c|c|c|c|}
\hline Compound & $v(\mathrm{C}-\mathrm{S})$ & $\begin{array}{l}v(\mathrm{C}=\mathrm{O}) \\
(\mathrm{DMF})\end{array}$ & $\begin{array}{l}v_{\text {as }}(\mathrm{COO}) \\
\text { (Acetate) }\end{array}$ & $\begin{array}{l}v_{\mathrm{s}}(\mathrm{COO}) \\
\text { (Acetate) }\end{array}$ & $\begin{array}{c}v(\mathrm{C}-\mathrm{O}) \\
\text { (Phenolic) }\end{array}$ & $v_{\max }$ & $\begin{array}{l}\text { Magnetic } \\
\text { Moment }^{\mathrm{a}} \\
\text { (B. M.) }\end{array}$ \\
\hline $\mathrm{PSCH}_{2}-\mathrm{LH}_{2}$ (II) & 840 & - & - & - & 1540 & - & Diamagnetic \\
\hline $\begin{array}{c}{\left[\mathrm{PSCH}_{2-}\right.} \\
\left.\mathrm{LHMn}(\mathrm{OAc})(\mathrm{DMF})_{3}\right] \\
(\mathrm{III})\end{array}$ & 820 & 1655 & 1585 & 1350 & 1545 & $\begin{array}{l}18000, \\
21230, \\
24890\end{array}$ & 5.65 \\
\hline $\begin{array}{c}\mathrm{PSCH}_{2-}- \\
\mathrm{LHCd}(\mathrm{OAc})(\mathrm{DMF})] \\
(\mathrm{IV})\end{array}$ & 815 & 1660 & 1610 & 1370 & 1550 & - & Diamagnetic \\
\hline
\end{tabular}

${ }^{\mathrm{a}} \mu_{\mathrm{eff} .}=2.83\left(\chi_{\mathrm{M}}^{\text {corr }} \times T\right)^{1 / 2} \mathrm{~B} . \mathrm{M}$.

The $v_{\mathrm{as}}(\mathrm{COO})$ and $v_{\mathrm{s}}(\mathrm{COO})$ stretches of free acetate ions occur at 1560 and $1416 \mathrm{~cm}^{-1}$ respectively ${ }^{20}$. The $v_{\mathrm{as}}(\mathrm{COO})$ and the $v_{\mathrm{s}}(\mathrm{COO})$ stretches occur at $1585 ; 1610$ and $1350 ; 1370 \mathrm{~cm}^{-1}$ in the compounds. The magnitude of energy separation $\left(\Delta v=235\right.$ and $\left.240 \mathrm{~cm}^{-1}\right)$ between $v_{\text {as }}(\mathrm{COO})$ and $v_{\mathrm{s}}(\mathrm{COO})$ is $>144 \mathrm{~cm}^{-1}$ and it indicates the monodentate nature of acetato groups ${ }^{20}$, since in bidentate coordination, the energy separation between $v_{\mathrm{as}}(\mathrm{COO})$ and $v_{\mathrm{s}}(\mathrm{COO})$ is $<144 \mathrm{~cm}^{-1}$. DMF shows a band at $1680 \mathrm{~cm}^{-1}$ due to the $v(\mathrm{C}==\mathrm{O})$ stretch $^{21}$. It shifts to lower energy by 25 and $20 \mathrm{~cm}^{-1}$ respectively in III and IV indicating the involvement of $\mathrm{O}$ atom towards coordination ${ }^{21}$.

\section{Magnetic Measurements}

The value of the magnetic moment of $\left[\mathrm{PSCH}_{2}-\mathrm{LHMn}(\mathrm{POAc})(\mathrm{DMF})_{3}\right]$ is $5.65 \mathrm{~B} . \mathrm{M}$ (Table-2). It indicates the magnetically dilute nature of the compound. [ $\left.\mathrm{PSCH}_{2}-\mathrm{LHCd}(\mathrm{OAc})(\mathrm{DMF})\right]$ is diamagnetic in nature.

\section{Reflectance Spectral Studies}

$\left[\mathrm{PSCH}_{2}-\mathrm{LHMn}(\mathrm{OAc})(\mathrm{DMF})_{3}\right]$ exhibits three bands at 18000,21230 and $24890 \mathrm{~cm}^{-1}$ due to ${ }^{6} A_{1 \mathrm{~g}} \rightarrow$ ${ }^{4} T_{1 \mathrm{~g}}(G),{ }^{6} A_{1 \mathrm{~g}} \rightarrow{ }^{4} T_{2 \mathrm{~g}}(G)$ and ${ }^{6} A_{1 \mathrm{~g}} \rightarrow{ }^{4} A_{1 \mathrm{~g}}(G)$ transitions, respectively in an octahedral symmetry ${ }^{22}$ (Table-2).

\section{CONCLUSION}

The elemental analyses, IR, reflectance and magnetic susceptibility measurements suggest an octahedral structure for $\left[\mathrm{PSCH}_{2}-\mathrm{LHMn}(\mathrm{OAc})(\mathrm{DMF})_{3}\right]$ (III) and a tetrahedral structure for $\left[\mathrm{PSCH}_{2}-\right.$ $\mathrm{LHCd}(\mathrm{OAc})(\mathrm{DMF})](\mathbf{I V})$.

\section{REFERENCES}

1. A.S. Abd-El-Aziz, P.O. Shipman, B.N. Boden and W.S. McNeil, Prog. Polym. Sci., 35, 714(2010), DOI:10.1016/j.progpolymsci.2010.01.004

2. S. Ficht, M. M. Mulbaier and A. Giannis, Tetrahedron, 57, 4863(2001), DOI:10.1016/S00404020(01)00424-0

3. M. R. Maurya, M. Kumar, A. Kumar and J.C. Pessoa, Dalton Transactions, 4220(2008), DOI: $10.1039 / \mathrm{B} 804823 \mathrm{~A}$

4. R. G. Phillips and J. S. Fritz, Analytica Chimica Acta, 139, 237(1982), DOI:10.1016/S00032670(01)94001-2

5. R.B. Merrifield, Journal of the American Chemical Society, 85, 2149(1963), DOI: 10.1021/ja00897a025

6. S.A. Patel, S. Sinha, A.N. Mishra, B.V. Kamath and R.N. Ram, J. Mol. Cat. A: Chem., 53, 192 (2003). 
7. V.B. Valodkar, G.L. Tembe, M. Ravindranathan, R.N. Ram and H.S. Rama, J. Mol. Cat. A: Chem., 31, 208(2004), DOI:10.1016/j.molcata.2003.07.001

8. M. Takahashi, A. Tsuji, M. Chiba and S. Itsuno, React. \& Funct. Polym., 65, 1(2005), DOI:10.1016/j.reactfunctpolym.2004.11.007

9. A. Prakash and D. Adhikari, Int. J. Chem. Tech. Res., 3, 1891(2011).

10. N. Novoa, J.P. Soto, R. Henríquez, C. Manzur, D. Carrillo and J. Hamon, J. Inorganic and Organometallic Polymers and Materials, 23, 1247(2013).

11. K.K. Girish and J.K.Saji, Reactive \& Functional Polymers, 66, 1427(2006).

12. B. De Clereq and F. Verpoort, Adv. Synth. Catal., 344, 639(2002).

13. K. Llango and S. Arunkumar, Rasayan J. Chem., 3(3), 493(2010).

14. R.R. Mishra, K.S. Nimavat and K.B. Vyas, Rasayan J. Chem., 5(2), 214(2012).

15. D. Kumar and A. Kumar, Bulgarian Chemical Communications, 48(4), 593(2016).

16. D. Kumar, A. Kumar, D. Dass and P.K. Gupta, Rasayan J. Chem., 8(4), 465(2015).

17. D. Kumar, D. Dass and A. Kumar, Bulgarian Chemical Communications, 47(2), 647(2015).

18. D. Kumar and A. Kumar, J. Chem., 2014, Article ID 124790, 1 (2014).

19. D. Kumar, A. Kumar and D. Dass, Bull. Chem. Soc. Ethiop., 28,29(2014), DOI:10.4314/bcse.v28i1.4

20. B.N. Figgis and R.S. Nyholm, J. Chem. Soc., 331(1959), DOI: 10.1039/JR9590000338

21. D. Kumar, P. K. Gupta, A. Kumar, D. Dass and A. Syamal; Journal Coordination Chemistry, 64, 590(2011), DOI: 10.1080/00958972.2011.552108

22. A B P Lever, Inorganic Electronic Spectroscopy, $2^{\text {nd }}$ edn., Elsevier, Amsterdam, 1984 and references therein.

[RJC-5081/2018] 